\title{
Transformativ læring på masteruddannelsen
}

TRANSFORMATIV LAERING • AKTIVERENDE UNDERVISNING AKTIONSLAERING • PEER LEARNING - CASE-UNDERVISNING VOKSENPAEDAGOGIK

Poul Erik Mouritzen og 


\section{Transformativ læring på masteruddannelsen}

TRANSFORMATIV LAERING • AKTIVERENDE UNDERVISNING AKTIONSL/ERING • PEER LEARNING • CASE-UNDERVISNING VOKSENPADAGOGIK

Kan man uddanne sig til at blive en dygtigere leder? Det spørgsmål er relevant for alle masteruddannelser og mange andre uddannelser og kurser i ledelse. Svaret i denne artikel er et betinget ja. Betinget, fordi det ikke er ligegyldigt, hvordan lederuddannelser udformes, og hvilke pædagogiske og didaktiske principper, der anvendes i undervisningen. Det skyldes at effekten på deltagernes ledelsespraksis afhænger både af deres viden, deres refleksionsevne og af deres personlige mod til at bruge deres viden og refleksioner til at forandre udøvelsen af ledelse i praksis. I denne artikel redegør vi for den teoretiske baggrund for og den praktiske implementering heraf $i$ et konkret masterfag i strategisk pædagogisk lederskab i skolen.

TAK

Tak til to reviewers for konstruktive kommentarer til en tidligere version af denne artikel. 


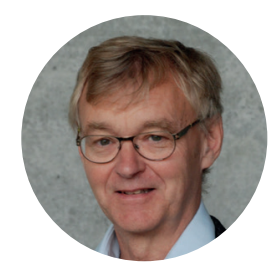

\section{Poul Erik Mouritzen}

Poul Erik Mouritzen er cand.scient.pol. fra Aarhus Universitet 1977, dr.scient.pol. fra samme sted i 1991 og har været professor på SDU og Aarhus Universitet. De seneste mange år har en stor del af hans undervisning ligget på forskellige masteruddannelser, siden 2015 på MPG som ekstern lektor. Hans forskning har primært fokuseret på offentlig organisation og ledelse, ikke mindst i kommunerne. Har på det seneste fokuseret på universitetsledelse.

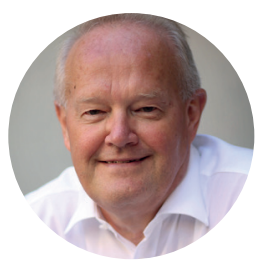

\section{Jørgen Søndergaard}

Jørgen Søndergaard er cand.oecon. fra 1974 og var ansat som adjunkt og lektor ved Aarhus universitet i 10 år og har derefter været leder af statslige institutioner $\mathrm{i}$ 28 år, senest som direktør for det daværende SFI. Har 35 års undervisningserfaring fra forskellige universiteter samt fra en omfattende formidling i forbindelse med deltagelse i en lang række kommissioner og ekspertudvalg. Jørgen Søndergaard er nu ekstern lektor ved CBS og senior fellow i tænketanken KRAKA. 


\section{Indledning}

"Reflection enables us to correct distortions in our beliefs and errors in problemsolving. Critical reflection involves a critique of the presuppositions on which our beliefs have been built. Learning may be defined as 'the process of making a new or revised interpretation of the meaning of an experience, which guides subsequent understanding, appreciation and action'."

(Mezirow 1990, 1)

Det er en gave at undervise ledere - hvis man vel at mærke tør pakke gaven op.

Gaven består i, at ledere har en lang række erfaringer og en dagligdag fyldt med ledelsesmæssige udfordringer. Men at udnytte det potentiale som ligger $\mathrm{i}$, at ledere har en praksis, kommer ikke af sig selv. Det kræver, ligesom ledelse gør det, et vist mod til at vove sig ud i ukendt terræn, hvor ikke alt kan være planlagt.

Enhver leder kan lære, hvad der skal til for at lede en organisation. At praktisere det er imidlertid noget helt andet (Bregman 2013). Vi har det udgangspunkt, at barriererne for god ledelse ikke så meget ligger i manglende viden, men i nok så høj grad i manglende mod. Barriererne findes i lederens hoved (og mave), og hvis ikke man arbejder med det aspekt, kan man ikke skabe permanente ændringer i ledelsespraksis.

Med dette som udgangspunkt har vi udviklet et masterfag rettet mod skoleledere og andre ledere i skolerne med titlen "Strategisk pædagogisk lederskab i skolen".

Faget løber over 14 måneder med i alt 21 mødedage, typisk organiseret som tredagesinternater. I meget grove træk søger det første semester at styrke deltagernes evner til at fortolke og analysere deres omgivelser og organisation, mens det andet er mere fremadskuende, idet deltagerne skal planlægge og gennemføre (eller starte gennemførelsen af) en større forandring på deres skole. Faget har et pensum $\mathrm{i}$ omegnen af 2000 sider og afsluttes med en eksamen baseret på pensum samt tre afleverede opgaver, hvoraf den sidste er en udviklingsplan for deltagernes skole. Deltagerne inddeles i netværksgrupper med typisk 5-6 deltagere, som er sammen gennem hele forløbet. Det typiske deltagertal har været på 25, som er en optimal holdstørrelse. Den øvre grænse går ved ca. 30 deltagere, fordi det er afgørende, at de to undervisere bliver fortrolige med deltagernes praksis og udfordringer.

I denne artikel vil vi redegøre for vores pædagogiske og didaktiske tilgang i dette fag og for vores erfaringer baseret på fire årgange af studerende. De grundlæggende pædagogiske ideer er ikke nye, men vi er ikke bekendt med, at nogen tidligere har kombineret og omsat disse i et konkret undervisningsforløb på samme måde, som vi har. Artiklens sigte er at videregive disse erfaringer til tilrettelæggere og undervisere på såvel masteruddannelser i ledelse som andre former for lederkurser.

\section{Mindsets skal forandres, og de skal lære at forandre sig selv}

En simpel pædagogisk model antager, at der ligger en fond af viden, som skal formidles videre til de studerende. Lærerens rolle er at lette formidlingen og hjælpe de studerende til at forstå, hvad der er svært. Og uanset hvor gammeldags 
det lyder, er der jo noget om det. Universiteternes raison d' etre er skabelsen af "forskningsbaseret viden", og den skal selvfølgelig formidles ud i samfundet, bl.a. gennem masteruddannelserne. Men at slutte der ville være en alvorlig fejttagelse, fordi masteruddannelserne så slet ikke får udnyttet samspillet mellem teori og praksis.

Alle mennesker guides i dagligdagen af deres såkaldte mindsets, ${ }^{1}$ der er en samlebetegnelse for - overvejende ubevidste - antagelser, som "selectively shape and delimit expectations, perceptions, cognition, and feelings" (Mezirow 1997, 5). Sådanne antagelser definerer, hvad vi finder vigtigt, behageligt og muligt såvel som betydningsløst, uvæsentligt og umuligt. Mindsets definerer, hvad det er, vi ser i vores omgivelser, og hvordan vi agerer i disse omgivelser. De har foruden en kognitiv også en emotionel komponent.

Den kognitive komponent er den del af mindsettet, der hjælper os til at filtrere, simplificere og fortolke vores omgivelser, og som dermed er en væsentlig determinant for, hvad vi ser, og hvordan vi agerer. Sådanne programmerede perceptioner kan have forskellige kilder: barndom, skole, uddannelse, joberfaring og den private sfære.

Den emotionelle komponent, der ligeledes kan have mange kilder fra oplevelser og erfaringer fra barndom, opvækst osv., omfatter de følelser af usikkerhed, ubehag og angst, som er den primære årsag til, at ledere langtfra altid gør det, der kræves eller ville være det mest virkningsfulde i den givne situation. Derfor bør en del af ethvert lederuddannelsesforløb bestå i at udfordre deltagerne til at træde ud af deres komfortzone, så de tager personlige risici og lærer at forstå kilderne til deres ubehag og usikkerhed i deres ageren med andre mennesker. At arbejde systematisk og langsigtet med den emotionelle komponent i ledelse bør med andre ord være en integreret del af et fornuftigt lederuddannelsesprogram. Med et moderne (dansk) udtryk taler vi om "det personlige lederskab".

Grundlæggeren af den såkaldte transformative læringsteori, Jack Mezirow, sondrede mellem forskellige former for læring ordnet efter størrelsen af den forandring, der sker i det lærende individs mindset (Mezirow 1990; 1997:7; Mezirow et al. 2009).

\author{
Forstærkning ${ }^{3}$ finder sted, når individer på det ubevidste plan støder på \\ evidens, der understøtter deres mindset. Fornyelse finder sted, når vi står over \\ for noget fremmedartet, som vi forsøger at finde mening i med vores eksister- \\ ende antagelser (mind-sets), men uden at vi i øvrigt betvivler antagelsernes \\ rigtighed. Transformering dækker over, at vi gennem mødet med virkeligheden \\ bliver tvunget til at sætte spørgsmålstegn ved vores grundlæggende antagelser \\ og eventuelt helt opgiver nogle af dem og erstatter dem med nogle helt nye.
}

\footnotetext{
1 I litteraturen bruges andre termer om det samme begreb, fx frames of reference (Mezirow 1997), mental models (Yeo and Gold 2011, 517) eller frames (Bolman and Deal 2013, 36-38). Begrebet er også beslægtet med Weick's teori om meningsskabelse i organisationer, hvor fx identitet og identifikation ses som determinanter for menningsskabelse. (Weick 1995).
}

2 En direkte oversættelse til engelsk af begrebet "det personlige lederskab" giver ingen mening. På engelsk findes begrebet "self-leadership" som langt henad vejen dækker over det samme, som vi på dansk tænker på, når vi taler om det personlige lederskab (se Bryant og Kazan 2013).

3 Termerne er ikke Mezirows men vores. 
Sådanne "mind-changing events" behøver ikke at være en engangsforeteelse, men det afgørende er, at de bliver udløst af i denne sammenhæng tilfældige hændelser, der får os til at se nogle åbenlyse mangler i vores mindset.

Dette bringer os til den vigtigste form for læring - den hvor vores mindset løbende udfordrer sig selv med henblik på fornyelse, jf. Argyris' model for double loop learning (Argyris 1982). Mezirow taler i den forbindelse om critical reflection som evnen til løbende at revurdere "the way we have posed problems" and "our own orientation to perceiving, knowing, believing, feeling and acting" (Mezirow 1990).

\section{En god lederuddannelse, der skaber "lasting behavioural change" (Revans 2011, 7), bør derfor kontinuerligt udvikle og benytte pædagogiske principper, der løbende udfordrer lederne til at reflektere over deres tilbøjelighed til at definere problemer og opfatte og fortolke deres omgivelser på bestemte måder; at reflektere over, hvordan de "ved", og hvor deres trossystemer stammer fra; og endelig til at reflektere over deres tilbøjeligheder til føle og agere på bestemte måder.}

Lederuddannelse skal skabe et nyt mindset, der gør, at lederen i al fremtid løbende vil sætte spørgsmålstegn ved og udfordre sine egne mindsets. Det vil samtidig sætte lederen bedre i stand til at forstå andres mindset og adfærd.

\section{Den transformative læringstrekant}

Det er næppe unormalt at betragte en lederuddannelse som en "helle" i en travl hverdag. Læringsaktiviteterne er det, der foregår i "klassen". Men vi har det modsatte syn - vi ser uddannelsesaktiviteter, der skal have langsigtede effekter som en integreret del af en travl hverdag, hvor deltagerne bringer deres hverdag med ind $\mathrm{i}$ uddannelsesaktiviteterne i "klassen" og bringer uddannelsesaktiviteterne med hjem i deres hverdag og herigennem inspireres til løbende at reflektere både over teorier, forskningsresultater og egen praksis. Dette er illustreret i figur 1.

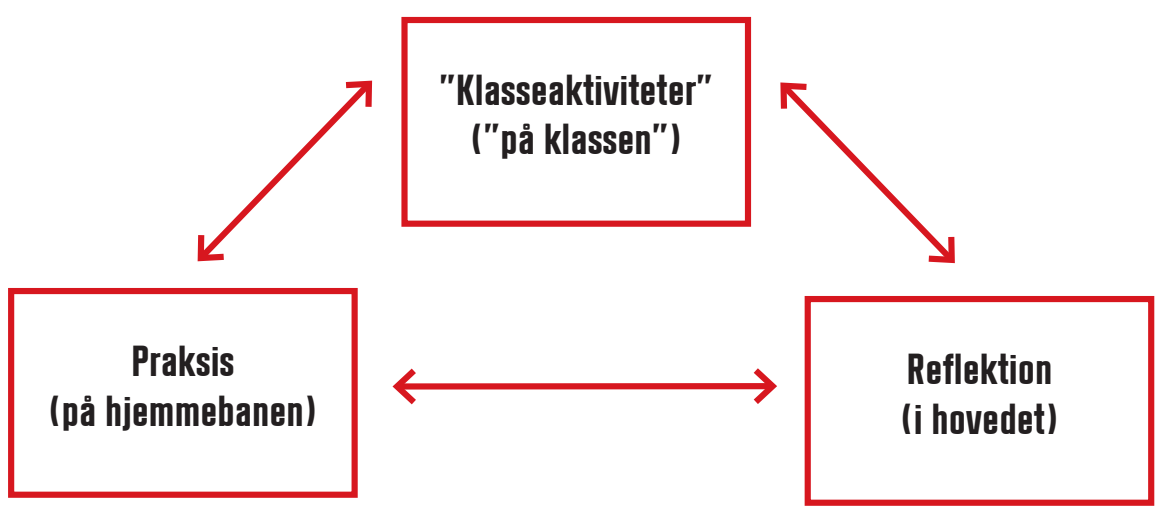

Figur 1. Den tranformative læringstrekant

Pointen i figuren er, at aktiviteter i "klassen" kun er et blandt tre elementer i læringsprocessen. Klasseaktiviteterne (af mange forskellige typer, jf. nedenfor) tvinger 
deltagerne til at reflektere men også til at arbejde med konkrete opgaver i deres ledelsesjob. Her gør de sig erfaringer, som sammen med de deraf følgende refleksioner bringes tilbage i klassen, hvor de (delvis) påvirker, hvad der så skal ske (double loop learning).

I planlægningen af et fag, der skal bæres af ovenstående ideer, er det således undervisernes job at sikre ikke bare et fornuftigt indhold og forløb af den enkelte time eller det enkelte modul men at skabe et samlet integreret forløb under anvendelse af en flerhed af pædagogiske principper, der skaber "lasting behavioral change".

Hvordan gør man så det? Nedenfor vil vi beskrive ti pædagogiske principper eller værktøjer, som vi med stor succes har taget i brug i masterfaget for danske skoleledere. De er inspireret af vores tidligere erfaringer med lederudvikling og -uddannelse i form af meritgivende masteruddannelser såvel som kortere ikkemeritgivende kurser, og de korresponderer med hovedideerne i transformativ læringsteori såvel som med filosofien i 'action learning', 'double loop learning' og 'experiential learning theory' (Mezirow et al. 2009; Clawson og Haskins 2006; Guthri og Jones 2012; Argyris 1982; Yeo og Gold 2011; se også Holten et al. 2015). Principperne såvel som værktøjerne er stort set alle afprøvet tidligere, om end de ikke nødvendigvis har været integreret med hinanden i længere forløb, og de har bevist deres værdi i "what works?" studier (Leonard og Marquardt 2010; Crosby 2017). Skolelederfagets indhold og ikke mindst den anvendte pædagogik er desuden inspireret af studieture til lederuddannelser for skoleledere i Sverige, New Zealand, USA og Canada.

\section{Pædagogiske principper og arbejdsmetoder}

\section{- En filosofi om den gode leder}

Vi har en meget simpel filosofi om, hvilke forudsætninger der kræves for god ledelse. Den gode leder skal have:

- evnen til at systematisk at forstå og fortolke sine omgivelser, forstået både som den organisation, man er sat til at lede såvel som denne organisations ydre omgivelser

- viden om "teknologien" - den faglige viden om, hvordan organisationen kan skabe resultater - på det område, man er ansat til at lede

- evnen til at forstå og udvikle sig selv

Når det gælder evnen til at fortolke sine omgivelser handler det, jf. ovenfor, om at bevidstgøre deltagerne om deres tilbøjelighed til at benytte bestemte mindsets og ligeså vigtigt - at træne dem i at benytte alternative fortolkningsrammer. Vi benytter (med stor gennemslagskraft blandt deltagerne) Lee Bolman's and Terrence Deal's Reframing Organizations, som systematisk træner læseren i at bruge fire forskellige fortolkningsrammer, den strukturelle (rationelle) ramme, human resource-rammen, den politiske ramme samt den symbolske (kulturelle) ramme. 
Viden om, hvordan man som leder skaber resultater, afhænger af organisationens faglighed. Både en politiinspektør og en skoleleder skal udvikle såvel evnen til at forstå deres omgivelser og evnen til at forstå sig selv. Men fagligt set - det vi kalder 'teknologien' - skal de kunne noget forskelligt. Politiinspektøren skal vide noget om, hvordan organisationen bedst fanger forbrydere; skolelederen skal vide, hvordan skolen bedst skaber læring hos eleverne. Af den grund bør en lederuddannelse også indeholde nogle elementer, hvor det faglige integreres helst med begge de øvrige to "evner" (diskuteres nærmere i afslutningen).

Evnen til at forstå og udvikle sig selv vil blive omtalt i næste afsnit.

\section{- Professionel og personlig udvikling bør integreres}

I det seneste årti er det i stigende grad blevet påpeget, at også den personlige udvikling bør inkorporeres i lederuddannelser (Bregman 2013; Bryant and Kazan 2013).

At "undervise" i det personlige lederskab er ikke noget, der ligger lige til højrebenet for universiteterne og universitetslærere. Det er tankevækkende, at det blev dem påtvunget som en forudsætning for, at de kunne få adgang til globaliseringsmidlerne i forbindelse med oprustningen af masteruddannelserne i offentlig ledelse. Fra parterne var der i øvrigt en betydelig og velbegrundet skepsis over for om universiteterne kunne magte det, og derfor blev der i første omgang stillet krav om anvendelse af konsulentfirmaer til at dække denne del af den nye masteruddannelse.

At arbejde med sig selv som leder eller som person er ikke noget, der kommer af sig selv. Man skal nemlig have et venligt skub ud af den komfortzone, som vi alle helst vil befinde os i. Kun ved at erkende, hvor grænserne for ens komfortzone går, hvorfor grænserne findes, og hvordan man har det med at arbejde uden for zonen, kan ledere stille og roligt tilskyndes til at arbejde med den emotionelle side af deres mindsets og dermed udvikle deres "emotionelle mod" (Bregman 2013).

Vi anvender i den forbindelse fire sæt af instrumenter:

Hver deltager får tilbudt en personlig test ${ }^{4}$ efterfulgt af en to-timers personlig samtale med uddannede erhvervspsykologer, som i en række efterfølgende fællessessioner fokuserer på vores dybtliggende dispositioner for magt og kontrol, inklusion og åbenhed og hvilke konsekvenser, det har for vores relationer til andre mennesker.

For det andet bliver deltagerne fra den første dag udsat for en række tests eller surveys om emner som deres ledelsesstil, "sundheden" af deres ledelsesteam, ledelseskompetencer, involvering i skolens pædagogiske aktiviteter, konfliktløsningsstil (Shell, 2001) og endelig virkelighedsopfattelse og motivation blandt lærerne på skolen. Når et bestemt begreb diskuteres, sørger vi for (i det omfang det kan lade sige gøre), at den enkelte deltager foran sig har en profil af sig selv, sin ledelsesgruppe eller sin skole. Nogle af disse tests gennemføres både ved starten og mod slutningen af forløbet. Disse profiler beskriver ikke nødvendigvis en objektiv virkelighed. Vi opfatter dem snarere som et instrument, der skal få deltagerne til, ofte sammen med deres netværksgruppe, at reflektere over deres tilbøjeligheder og evner.

4 The Human Element testen er udviklet af den amerikanske psykolog Will Schutz (1994). Også kaldet FIRO-b testen. 
Et naturligt spørgsmål er, om de mange tests og profiler blot skaber forviring i deltagernes hoved. Det gælder ikke mindst de meget personlige tests. Vi gør meget ud af at fortælle vores studerende, at de selv skal vælge de aspekter ud, som de vil arbejde videre med: "Vælg den eller de testresultater, som har givet mest anledning til refleksion og tanker om, hvor du gerne vil udvikle dig." De mest reflekterede studerende formår faktisk at integrere en god del af testene til at formulere et samlet billede af sig selv, og hvor de ser et behov for udvikling.

Hver deltager skal for det tredje aflevere en skriftlig case baseret på eget emnevalg, dog med et krav om, at den skal omhandle et forløb (historisk eller aktuelt), som har givet vedkommende store udfordringer eller bekymringer. Den mest typiske case handler om dysfunktionelle ledelsesteams ude på skolerne. En af effekterne af disse cases var til vores overraskelse, at udviklingen af casen også for en del deltagere var en psykologisk frigørelsesproces, fordi den gav anledning til refleksioner over egne følelser og adfærd og baggrunden for disse. En af deltagerne udtrykte det på følgende måde: "Jeg var overrasket over, at arbejdet med casen havde en psykologisk helengseffekt. Jeg følte mig bedre tilpas med forløbet, og derfor følte jeg også, at jeg havde en række muligheder, hvis sagen skulle opstå igen" (refleksive interviews). Vi kan blot gisne om årsagerne til denne effekt. Måske er der en pointe i at få lov til - i tredje person - at fortælle om en dilemmafyldt eller endog traumatisk begivenhed, hvor man selv er/var hovedperson, og hvor man gerne må give aktørerne inkl. én selv opdigtede navne som i en novelle baseret på egne oplevelser?

Endelig kræves for det fjerde, at deltagerne som led i den afsluttende udviklingsplan skriver nogle sider om, hvordan de har arbejdet med deres personlige udvikling i forbindelse med faget. Vi opfordrer lederne til løbende at reflektere over og arbejde systematisk med deres personlige udvikling, ikke mindst på baggrund af inspiration til frygtløs ledelse ( Henriksen og Lundby 2016) og de profiler, de løbende har fået udleveret, og til at nedskrive deres erfaringer i en logbog (om "reflective assessment portfolios", se Donaldson 2009, 73f).

Det skal nævnes, at alle disse aktiviteter, der har til formål at udvikle det personlige lederskab, anvendes i direkte sammenhæng med de udfordringer, deltagerne står overfor på deres hjemmebane. Professionel og personlig udvikling er således stærkt integreret. De mange forskellige "spejle" vi forsyner de studerende med, viser naturligvis ikke ens billeder endsige et konsistent sæt af billeder af personen. Vores erfaring er, at det varierer fra deltager til deltager, hvilke spejle vedkommende bliver mest overrasket over eller inspireret af. Men sammen med dialogerne med underviserne og med de medstuderende har vi erfaret, at fremgangsmåden skaber en åbenhed omkring det personlige, som er det første skridt mod at arbejde bevidst med personlig lederudvikling.

\section{- Integration af teori og praksis}

Aktionslæring "is cradled in the very task itself, asking whether that task can be done so that, merely reflecting upon how it currently seems to be done, the very doing it supplies the learning generally offered far from the scenes of managerial activity" (Revans 2011, 3). Fra den første dag i forløbet opfordres deltagerne til at tænke på deres organisation og på de udfordringer, den står overfor. En central 
del af aktiviteterne i første semester træner deltagerne i at forstå, hvordan deres organisation fungerer. Det starter med en simpel SWOT-analyse (SWOT= Strengths, Weaknesses, Opportunities and Threats), som enkelte af deltagerne har lavet før. Det typiske for SWOT-analyser er, at de er en engangsforeteelse, som derefter kan lægges ned i en skrivebordsskuffe. I vores sammenhæng er den første SWOT imidlertid blot starten på en længere rejse - med "Reframing Organizations" og Vivianne Robinsons forskningsoversigt over skolens "teknologi" (hvordan skoler skaber læring for eleverne; Robinson 2011) som rejsefører - ind i krinkelkrogene på ens skole. Efter det første halve år er den oprindelige SWOT-analyse blevet langt mere raffineret og målrettet mod konkrete udviklingsmål, fordi den løbende opdateres, efterhånden som deltagerne bliver klogere på de forskellige perspektiver, der kan anlægges på organisationen, og på hvilke styrker og svagheder der er de vigtigste. Fra dette tidspunkt er deltagerne klar til at se fremad i form af en udviklingsplan, som helt naturligt kommer til at tage sit afsæt i skolens styrker, svagheder etc.

\section{- Intensiv brug af hjemmeopgaver}

Efter hvert modul i "klassen" får deltagerne en hjemmeopgave, der handler om deres egen organisation. Det kan bestå i en ugentlig observation i et klasseværelse for at iagttage, hvordan svage elever aktiveres eller ikke aktiveres i undervisningen; deltagelse i et lærerteammøde om en vigtig pædagogisk udfordring; gennemførelse af en survey i ledelsesteamet om teamets effektivitet og diskussion af resultaterne på et ledermøde; gennemførelse og evaluering af ændringer i ledelsens mødestruktur; sammen med ledelsesteamet træffe beslutning om, hvordan ledelsen sikrer tid til strategiske opgaver og ikke drukner i dag-til-dag opgaver; overvejelse af ens forhandlingsstil og hvordan man vil forberede og træne vanskelige samtaler og forhandlinger. Vi understøtter det intensive arbejde med hjemmeopgaver ved at sørge for, at arbejdet med hjemmeopgaven også bliver behandlet i læreringsgrupperne. Dernæst er en del af hjemmeopgaverne starten på et undervisningsforløb, næste gang vi mødes i "klassen".

\section{- Intensiv anvendelse af cases i undervisningen.}

Baseret på den løbende såvel som den afsluttende evaluering af faget ser vi et meget stort læringspotentiale i brugen af cases skrevet og undervist efter Harvard-modellen (se f.eks. Sweet et al., 1992), og vi har skrevet omkring ti cases til vores undervisning baseret på materiale og interviews fra en række danske skoler. Desuden anvender vi nogle få amerikanske cases. En af pointerne ved brug af cases i undervisningen er ifølge Revans (2011, 80-82), at deltagerne genkender setuppet, men ikke er personligt ansvarlige for hverken "diagnose" eller "behandling" i den konkrete case. Der kan også være fordele ved cases baseret på en deltagers personlige erfaringer, og alle deltagere i vores fag skriver en personlig case, som de diskuterer i deres netværksgruppe (se nedenfor), men af tidsmæssige grunde er det sjældent muligt at bringe deltagernes egne cases ind i klasseværelset.

\section{- Peer leadership training}

Peer leadership training er en potentielt vigtig kilde til læring. Derfor anvender vi grup- 
pearbejde i de samme netværksgrupper på 5-6 deltagere gennem hele forløbet. På den måde opnår vi en form for professionelt læringsfællesskab, hvor deltagerne i hver gruppe har aftalt klare "spilleregler" for deres indbyrdes relationer. Resultatet er, at gruppemedlemmerne opnår et indgående kendskab til hinanden og en stor indbyrdes åbenhed, som er uhyre fremmende for gensidig læring. Arbejdet i grupperne foregår på gruppernes eget ansvar, og vi er som undervisere kun involveret, hvis der opstår behov for afklaring eller vejledning. Det skaber en høj grad af seriøsitet i gruppearbejdet, fordi deltagerne uden indblanding kan drøfte hinandens mest påtrængende og personlige udfordringer. Netværksgrupperne er desuden en "træningsbane" for lederne i forhold til at udvikle professionelle læringsfællesskaber for lærerne på deres skoler.

\section{- Undervisere er både facilitatorer, instruktorer og vejledere}

Vores opgave som undervisere er at sikre integration og sammenhænge mellem de mange forskellige elementer i uddannelsesforløbet og deltagernes egen praksis. I den forstand bliver vi i høj grad facilitatorer af læreprocesser. Der indgår naturligvis også forelæsninger som i mere traditionel universitetsundervisning, men vi tilstræber at begrænse omfanget af forelæsninger både med hensyn til antal og med hensyn til den enkelte forelæsnings varighed. Vores mål er, at en forelæsning højst bør vare 30 minutter plus tid til diskussion, men det er ikke altid, vi kan overholde det!

Den tredje vigtige rolle for underviserne er individuel vejledning og coaching af deltagerne gennem hele undervisningsforløbet. Fra den første dag deler vi to undervisere vejledningsopgaven mellem os, så hver deltager har den samme vejleder gennem hele forløbet. Dele af vejledningen er planlagt, men deltagerne kan frit selv tage kontakt til deres vejleder om et hvilket som helst emne, hvad enten det drejer sig om faget eller om udfordringer på deres skole. Denne tætte kontakt mellem undervisere og deltagere kan dels bidrage til, at deltagerne (forhåbentligt) får løst nogle af deres udfordringer, og dels til at underviserne opnår en bedre forståelse af den virkelighed, deltagerne arbejder i på deres hjemmebane - en forståelse som er værdifuld for undervisernes mulighed for at skabe integration mellem undervisning og deltagernes praksis. Der er en yderligere fordel ved denne "nærkontakt" til deltagernes praksis: Det giver os som undervisere et input til løbende refleksion over relevansen af de forskellige komponenter (emner og problemstillinger) i forløbet såvel som valget af pædagogiske metoder og redskaber. På den måde opnår vi som undervisere et reflektionsredskab svarende til det, Revans $(2011,9)$ kalder "action learning of the second order."

Vi har en række eksempler på, at det nære kendskab til deltagerne har ført til ændringer i indholdet af faget. Et eksempel herpå var, at vi på hold 2 kunne se, at deltagerne stod overfor betydelige problemer med at få skolernes ledelsesteams til at fungere. Her indførte vi et langt forløb dækkende to semestre, der handlede om udviklingen af ledelsesteams, hvor deltagerne inddrog deres medledere ude på skolerne, naturligvis på frivillig basis idet problemerne i teamet kunne være så store, at der var behov for mere intensiv indsats under medvirken af konsulenter eller erhvervspsykologer.

I mange lederuddannelser optræder et større antal undervisere og gæsteforelæsere. Vi anvender også nogle få gæsteundervisere, men vi er overbeviste om, at opgaven med at sikre integration og sammenhæng kun kan løses ved, at vi begge altid er tilstede. 
Gæsteundervisere kan bringe specifikke perspektiver ind i undervisningen, men det får kun for alvor værdi, hvis vi sørger for, at det bliver integreret i det samlede forløb.

Det meget tætte kendskab til deltagerne og deres situation samt det forhold, at vi kan have rådgivet dem om ømtålelige personlige dilemmaer kunne potentielt skabe problemer i forbindelse med eksamen. Et aspekt af problemet er, om vi kan undlade at lade os farve af kendskabet til dybe personlige problemer eller overvejelser hos den enkelte, fx. i form af at nogle ledere gennem forløbet erkender, at de nok ikke burde være ledere eller ledere på den plads, de har nu og af den grund har mistet en del af motivationen, eller at de er blevet fyret to måneder før eksamen. Problemet er tilstede i enhver form for mundtlig eksamen, hvor antipatier eller sympatier kan spille ind, men det er forstørret i netop dette fag på grund af den meget tætte relation til eksaminanden. Man må derfor i den fjerde rolle - som eksaminator - være sig meget bevidst om risikoen for at ens mindset kan være påvirket af forløbet og handle så professionelt som overhovedet muligt.

\section{- Læring sker ikke kun i klasseværelset, men også på hjemmebane}

Som allerede anført sker en væsentlig del af læringen for ledere, når de arbejder med deres egen ledelse i egne organisationer. Men hertil kommer, at der også skabes læring for andre medlemmer af organisationen. Det kan være ledelsesteamet eller medarbejdere, der som deltagere i en leders "aktionslæring", selv opnår ny indsigt. Det er en anden form for aktionslæring "of the second order". Vi har endvidere oplevet en anden form for dobbelt effekt. Noget af det, deltagerne oplever ved vores undervisningsform, opfattes som en model, der kan tages med hjem og anvendes i egen organisation. En af vores netværksgrupper fremhævede i deres fælles evaluering af forløbet, at "undervisernes tilgang til undervisningen er en model for, hvordan teorier og metoder anvendes i praksis. Det skaber et ekstra læringsniveau for os studerende, at vi ser vores undervisere praktisere denne kobling mellem teori og praksis". Eller som en skoleleder udtrykte det:" Jeg lærer også en række personlige og professionelle redskaber, som gør mig til en bedre leder af processer og lærende organisationer derhjemme på skolen".

\section{- Adfærdsændringer er det ultimative mål}

Et masterfag på et universitet er en del af et meritgivende system, som nødvendigvis må indeholde en eksamen. En af udfordringerne herved er at undgå, at deltagerne fokuserer for meget på eksamen og for lidt på refleksion og udvikling af en ændret lederadfærd. Det er ikke let, for mange deltagere har dannet sig en bestemt opfattelse af eksamenskravene ved at følge andre fag. Derfor gør vi meget ud af med jævne mellemrum at slå fast, at vi anser evnen til at reproducere den litteratur, vi anvender, for værdiløs i sig selv. Det afgørende er evnen til at anvende stoffet på en reflekteret måde i egen organisation og at arbejde med og reflektere over egen personlige udvikling som leder. Det kan illustreres med et par sætninger, vi bruger igen og igen: "Husk, du skriver ikke for os (underviserne) men for dig selv" og "Det eneste vigtige for os er, hvad du gør anderledes på din skole og hvorfor". En af deltagerne gav følgende tilbagemelding på forløbet: "Den måde, vi hele tiden får nye opgaver, er virkelig god. Fokus er på proces og anvendelse. Det er det samme med den udviklingsplan, vi skal aflevere til den endelige eksamen. Det 
er noget, vi udvikler for vores egen skyld, ikke for vores læreres skyld eller for at vise, at vi kan gengive en masse teori i et paper".

Det betyder selvfølgelig ikke, at deltagerne ikke skal sætte sig ind i det stof, vi gennemgår. Men vi lægger vægt på, at de bringer det i anvendelse, fordi de kan se en mening med det i deres praksis. Og vi kan sagtens afprøve, om de kan stoffet ved læsning af deres udviklingsplan og den mundtlige eksamen, uden at det behøver have en traditionel akademisk form.

\section{- At lære sig nye måder at udøve ledelse på tager tid}

Mange masterfag og andre lederkurser forløber over relativt kort tid (30-45 timer på et semester). Det er efter vores vurdering alt for lidt, hvis målet er at udvikle ny lederadfærd. Det kræver adskillige runder i trekanten, vi beskrev ovenfor, at forsøge sig frem til nye fremgangsmåder, der fungerer godt. Vi har fundet, at tre semestre fungerer godt. Vi afprøver for tiden et forløb over 14 måneder, som endnu ikke er afsluttet.

\section{Virker det integrerede forlab?}

Er vi lykkedes med at pakke gaven - at få lov at undervise ledere - op? Tre hold med i alt godt 70 deltagere har indtil nu afsluttet forløbet, mens det fjerde hold er tæt på afslutningen. Vi har set en række fremragende udviklingsplaner, hvor ledere både arbejder strategisk med udvikling af deres skoler og med sig selv. Og det er ikke bare planer - mange beretter til den afsluttende mundtlige eksamen om, at de er rigtig godt i gang med at føre planen ud i livet og om deres personlige udvikling gennem forløbet. Betyder det, at alle deltagere gennemgår en transformation? Nej, der er helt sikkert undtagelser. 10-15 pct. af deltagerne ændrer, så vidt vi kan bedømme, kun marginalt på deres lederadfærd. Det betyder ikke, at deres udbytte er nul, men effekten af deres deltagelse i uddannelsen på deres organisation må forventes at være forholdsvis begrænset. Men det store flertal undergår en større eller mindre transformation. Også i den forbindelse har vi gjort en vigtig erfaring:

\section{Der er en klar sammenhæng mellem lysten eller modet til at arbejde med den personlige side af lederskabet og så omfanget af ændringer på hjemmebanen. Kommer man ikke ud af komfortzonen, sker der med andre ord ikke de store forandringer.}

Og det afspejler sig også klart i, hvordan man klarer sig til eksamen.

Det understøttes af de evalueringer, der er gennemført ved afslutningen af hvert forløb. For alle tre hold omfattede evalueringerne deltagernes vurdering af effekten på deres evner til at tackle ti generelle ledelsesudfordringer i skolen. Og billedet er entydigt; de føler sig selv bedre rustet og især til de udfordringer, som de ved starten af forløbet anså for de vanskeligste.

Med hold 1 gennemførte vi et særligt omfattende evalueringsprogram (for at få så meget feedback som muligt som undervisere). Et af elementerne var refleksive interviews, hvor deltagerne i hver netværksgruppe interviewede hinanden om stærke 
og svage sider ved forløbet. Interviewene blev optaget på bånd og var en yderst værdifuld feedback til os som undervisere.

Et gennemgående udsagn fra evalueringerne og mundtlige tilbagemeldinger fra deltagerne har været, at denne form for undervisning har haft markant større relevans for deres dagligdag end alle de andre lederkurser og -uddannelser, de har deltaget i. Næsten alle har deltaget i lederuddannelser på diplomniveau, en mindre del på masterniveau, og endelig har nogle deltaget $\mathrm{i}$ andre ikke-meritgivende lederkurser af forskellig art.

\section{Det er et "både-og"}

I gennem flere årtier har der hos centrale beslutningstagere hersket den opfattelse, at lederuddannelser kunne have et frigørende potentiale, hvis blot ledere fra forskellige sektorer blev sat sammen. Derved kunne man få et kendskab til andre sektorer end ens egen, som dels kunne være til inspiration for udvikling af ens egen organisation, dels være et bidrag til at bryde silotænkning og snæversyn. En yderligere årsag til ønsket om tværsektorielle lederuddannelser var, at indholdet på fortidens lederuddannelser blev anset for blot at være en fortsættelse i den "osteklokke", som lederne havde kendt fra deres professionsuddannelse.

Det burde være overflødigt at nævne, at vi er uenige i, at det tværsektorielle skal gælde al offentlig lederuddannelse. Dårlig ledelse handler ikke først og fremmest om silotænkning. Det handler om, at lederne ikke magter at forstå deres omgivelser, ikke forstår sig selv og ej heller kan arbejde systematisk med viden om "teknologien" på deres område.

Ved udelukkende at undervise tværsektorielt taber man nogle enestående muligheder på gulvet, fordi det bliver meget vanskeligere at skabe transformativ læring. Ikke fordi man ikke kan lære noget af ledere fra andre sektorer, men fordi det sker på bekostning af den dybde og integration af teori og praksis og personlig udvikling, der er afgørende for transformativ læring, hvis al lederuddannelse skal være tværsektoriel. Det tværsektorielle kan bidrage med værdifuld inspiration, men er uegnet til at skabe rum og inspiration til at arbejde med de virkeligt svære ting. Derfor øges effekten af undervisning i forhold til at opnå transformativ læring, når undervisningen har fokus på at bistå de studerende med integrationen af teori og praksis, det organisatoriske og det faglige, det professionelle og det personlige osv., samtidig med at deltagerne arbejder i netværksgrupper med andre deltagere, der til fulde forstår karakteren og kompleksiteten af den enkeltes ledelsesmæssige udfordringer.

Også i forbindelse med debatten om reform af diplomuddannelsen for skoleledere har spørgsmålet om samlæsning med andre faggrupper versus skolespecifikke moduler været aktuelt. Vi kender ikke det præcise indhold af reformen, men vi har noteret os, at der sker en række ændringer, der indebærer et indslag af skolespecifikke moduler på uddannelsen med det sigte at styrke koblingen til praksis på deltagernes egne skoler. Noget tilsvarende ville være relevant for MPG.

Nu er det selvfølgelig heller ikke enten-eller. For naturligvis kan der være fornuft i, at man som led i diplom- eller masteruddannelser kan tage nogle fag sammen med 
andre faggrupper. Men omvendt bør der også være længerevarende sektorspecifikke forløb for ledere i hver af de sektorer, som er så store, at man kan nå op på en fornuftig volumen, det være sig skoleledere, institutledere, ledere i politiet, på hospitaler osv. Faktum er jo, at de er professionsuddannede og bliver - og forbliver - ledere inden for den pågældende sektor, bl.a. fordi man lærer noget om sektorens "teknologi" gennem sin professionsuddannelse og ved at praktisere denne. Derfor ser vi heller ikke ledere bevæge sig på tværs af sektorer. Læger kommer ikke til at være ledere i politiet og sygeplejersker kommer ikke til at lede en folkeskole. Vi er til gengæld af den overbevisning, at den model, vi har praktiseret, med succes kan overføres til andre professioner. Ja, for den sags skyld til lederuddannelser for ledere i den private sektor. Det eneste krav er, at deltagerne i et forløb ikke "må have noget på hinanden" - altså f.eks. ikke være ledere i organisationer, der er i indbyrdes konkurrence eller indgår i et over-/underordnelsesforhold. Lederuddannelse kan kun lykkes i et rum med stor gensidig tillid og åbenhed deltagerne imellem.

\section{Tor man?}

Vi skrev $\mathrm{i}$ indledningen, at det ikke lige ligger til højrebenet for universitetsundervisere at engagere sig i udviklingen af det personlige lederskab for ledere i den offentlige sektor.

Det er vigtigt at holde sig for øje, at det fulde potentiale i den pædagogiske og didaktiske tilgang til undervisning af ledere, vi har beskrevet i denne artikel, forudsætter, at underviserne også tør sætte sig selv i spil på en usædvanlig måde. Den gave, det er at undervisere ledere, kommer ikke af sig selv. Gaven skal pakkes op.

Man kan i den henseende sammenligne universitetsunderviseren med skolelederen. At undervise efter de ti principper, vi har skitseret ovenfor, er nemlig et godt stykke hen ad vejen et ledelsesjob, hvor man tvinges ud af komfortzonen, og hvor man er nødt til at sætte sig selv i spil. Tør man det, er det til gengæld en stor gave, man får som belønning: At opleve, at ens studerende med begejstring starter en personlig og professionel rejse mod ambitiøse mål om, at de vil være bedre ledere, fordi de har indset, at det er vejen til at udvikle deres skole, så eleverne i fremtiden bliver endnu dygtigere. 


\section{Litteratur}

Argyris, C. (1982). Reasoning, Learning og Action. San Francisco: Jossey-Bass.

Bolman, L.G. \& Deal, T.E. (2013). Reframing Organizations: Artistry, Choice and Leadership, 5th Edition, Jossey-Bass.

Bregman, P. (2013). Why so many leadership programs ultimately fail. Harvard Business Review. https://hbr.org/2013/07/why-so-many-leadership-program.

Bryant, A. \& Kazan, A. (2013). Self Leadership: How to Become a More Successful, Efficient and Effective Leader from the Inside Out. McGraw-Hill.

Clawson, J.G.S. \& Haskins, M.E. (2006). Teaching Management: A Field Guide for Professors, Consultants and Corporate Trainers. Cambridge University Press.

Crosby, B.C. (2017). Teaching Leadership: An Integrative Approach. Routledge.

Donaldson, J.F. (2009). Fostering transformative learning in leadership development. I J. Mezirow, E.W. Taylor \& Associates (Red.), Transformative Learning in Practice: Insights from Community, Workplace and Higher Education (s. 67-78). San Francisco: Jossey-Bass.

Guthrie, K.L. \& Jones, T.B. (2012). Teaching and learning: Using experiential learning and reflection for leadership education. New Directions for Student Services, 140, 53-63.

Henriksen, M.N. \& Lundby, T. (2016). Frygtløs Ledelse. København: Dansk Psykologisk Forlag.

Holten, A.-L., Bøllingtoft, A. \& Wilms, I. (2015). Leadership in a changing world: Developing managers through a teaching and learning programme. Management Decision, 53(5), 1107-1124.

Leonard, H.S. \& Marquardt, M.J. (2010). The evidence for the effectiveness of action learning. Action Learning: Research and Practice, 7(2), 121-136.

Mezirow, J. (1990). How critical reflection triggers transformative learning. I J. Mezirow, \& Associates (Red.), Fostering Critical Reflection in Adulthood: A Guide to Transformative and Emancipatory Learning (s. 1-21). San Francisco: Jossey-Bass.

Mezirow, J. (1997). Transformative learning: Theory to practice. New Directions for Adult and Continuing Education, 74, 5-12.

Mezirow, J., Taylor, E.W. \& Associates (2009). Transformative Learning in Practice: Insights from Community, Workplace and Higher Education. San Francisco: JosseyBass.

Revans, R. (2011). ABC of Action Learning. Gower Publishing Company.

Robinson, V. (2011). Student-centered Leadership, San Francisco: Jossey-Bass.

Schutz, W. (1994). The Human Element: Productivity, Self-Esteem, and the Bottom Line. San Francisco: Jossey-Bass. 
Shell, R.G. (2001). Bargaining Styles and Negotiation: The Thomas-Kilmann Conflict Mode Instrument in Negotiation Training. Negotiation Journal, 17(2), 155-174.

Sweet, A., Garvin, D.A. \& Christensen, C.R. (1992). Education for Judgment: The Artistry of Discussion Leadership. Harvard Business School.

Yeo, R.K. \& Gold, J. (2011). The inseparability of action and learning: Unravelling Revans' action learning theory for Human Resource Development (HRD). Human Resource Development International, 14(5), 511-526.

Weick, K. (1995). Sensemaking in Organisations. London: Sage. 